Brian H. Tress

As a senior manager in Ernst \& Young's Hospitality Advisory Services Group, Brian Tress has 14 years of real estate and hospitality experience including managing projects involving various types of hospitality real estate assets. He has assisted privateand public-sector entities throughout the USA, Canada, Asia and the Commonwealth of Independent States to develop hospitality projects with lasting economic benefits to all parties involved. Brian Tress has recently served as a speaker on panels regarding financing convention centres and management selection for conference centres, at the 2002 International Economic Development Council Conference on Sports and Conference Center

Development. He also frequently writes and speaks on hospitality trends, topics and technical issues.

Keywords:

bonds, capital, economic impact, equity, incentives, public-private partnerships, tax increment financing

\section{Using public-private partnerships to fund hotel development projects}

\author{
Brian H. Tress
}

Received: 22nd July 2002

\begin{abstract}
This paper discusses the private- and public-sector roles in jointly developing hospitality projects, including each sector's motivation and criteria for participating in these projects, and methods of financing them. Additionally, data on 36 public-private hotel projects across the USA is presented to highlight recent trends in hotel financing structures. These trends generally support the concept that large, first-class hotels in urban locations require some form of public participation to attract the necessary private financing and equity investment.
\end{abstract}

\section{INTRODUCTION}

In recent years the public sector has increasingly become a major factor in the revitalisation of urban locations throughout the USA. Either on its own or in partnership with the private sector, the public sector has acted in a variety of ways to invest in development for the purpose of breathing new life into cities. Frequently, economic revitalisation begins with the development of a large hospitality project, such as a convention headquarters hotel.

Restrained conditions in the capital markets with respect to hotel development projects - which are generally considered high risk relative to other real estate uses - coupled with high costs of development often result in a gap between available returns and those required by private sector investors. The public sector, acting as a conduit to improve economic conditions, can provide the incentives to bridge this gap. Public-private hospitality partnerships work to benefit each partner - private developers and owners achieve their desired return on investment, and public sector entities such as economic development agencies, convention centre authorities and transportation authorities gain from tax collections as well as economic benefits to the local community. By revitalising depressed downtown areas, cities can enjoy substantial financial benefits such as non-tax income from project operations, bed taxes, sales taxes and increased real estate taxes resulting from the project, as well as higher assessed values in the surrounding area. In addition, new businesses in the area create new jobs and attract supporting services. Civic leaders also realise that by creating public-private partnerships to make large development projects 
Impact on convention activity

\section{Impact on development}

possible, a 'ripple effect' is formed and other projects gain momentum.

Additionally, the development of a large full-service hotel - ie offering restaurant(s), meeting space, a fitness centre, retail outlet(s) and services such as room service and dry cleaning — adjacent or attached to a convention centre is often seen by municipalities as a way to enhance the city's competitive position as a convention destination. This is based on the preferences of event organisers, who prioritise the availability of a headquarters hotel (where convention delegates can eat, sleep and meet under one roof, in close proximity to the convention centre) in their selection of an event location. Cities that offer walkable/connected 'districts' with imaginative lodging, retail and food service choices - combined with public spaces and cultural/sports facilities - have been consistently successful as convention destinations. Those with stand-alone or 'stranded' convention centres do not compete as effectively.

\section{FINANCING HOTEL DEVELOPMENT}

\section{The conservative private sector}

This section provides an overview of private sector motivation, criteria and financing and investment vehicles for hotel development in the USA. In general, private sector investment in the hotel industry has become increasingly conservative over the past ten years. Beginning after the US recession in the early 1990s - when many lenders were forced to foreclose on hotel loans due to the combination of the depressed lodging market and aggressive underwriting criteria - loan to value (LTV) ratios shifted downward and debt service coverage (DSC) ratios upward, to levels that emphasised the newly recognised risk associated with the lodging sector. Additionally, more emphasis began to be placed on qualitative evaluation project by project, with optimal criteria set for location, property type, sponsorship and other factors. ${ }^{1}$ As development costs for hotel projects - particularly for first-class products in urban locations - continued to rise, the conservative financing environment put downward pressure on the annual hotel development pipeline, with equity in many cases unable to achieve the returns it desired. This environment, in large part, has been responsible for softening the blows of the last two years (ie the national recession and the events of September 11th) on the US hotel industry.

\section{Motivation}

Hotels have historically exhibited a long-term competitive advantage over other real estate investments. However, factors such as management intensiveness, significant fixed operating expenses and limited cash-flow stability relative to other real estate sectors increase the risk associated with the lodging sector as 


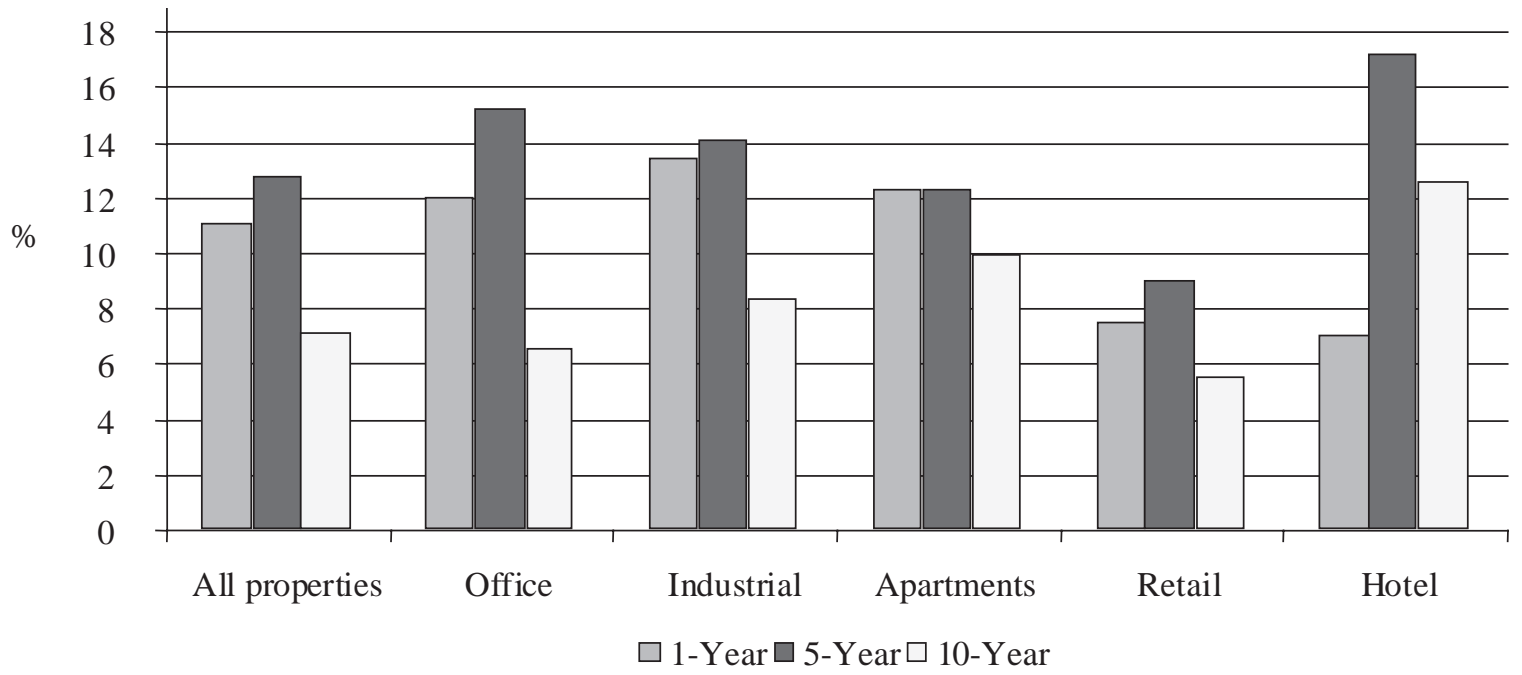

Figure 1: Annual compound total return - NCREIF index

Source: The National Council of Real Estate Investment Fiduciaries

\section{Critical factors for lenders}

well as magnifying conditions for the industry during economic downturn.

As seen in Figure 1, US hotels have outperformed on a five- and ten-year return basis, with a premium of 460 and 540 basis points, respectively, over the 'All properties' category. As an example, hotels have a 600 basis point premium over the office sector on a ten-year compounded annual return basis. ${ }^{2}$

\section{Criteria}

The primary drivers (ie assessment criteria) for private sector investment in US hotels include location, property type, asset performance and sponsorship, as discussed below.

- Location: Optimal criteria for hotel development include first-tier central business district (CBD) markets with limited potential for market volatility, diverse demand segmentation (ie mix of commercial, leisure and group business) and high barriers to entry.

- Property type: Favourable property types include first-class, branded full-service and extended-stay (targeting guests who stay five nights or longer) hotels with a strong franchise affiliation and operator. Budget-oriented limited-service hotels (ie without food and beverage facilities), mid-priced full-service hotels and boutique and other independent hotels are generally considered unfavourable property types with respect to potential private sector investment.

- Asset performance: Financing for to-be-built properties is extremely difficult to obtain, with lenders either not underwriting 
Debt and equity requirements these projects at all or requiring low leverage, excellent sponsorship and recourse. Emphasis is on refinancing of existing properties based on in-place earnings, rather than financing tobe-developed properties that require speculation. For example, in a report issued by Moody's Investors Service in August 2001, ${ }^{3}$ hotels were singled out as 'the riskiest asset class collateralizing commercial mortgage-backed securities'. Moody's cited that not only do hotels have to 'lease' their rooms daily, losing revenue for every unsold unit, but they also have the highest expense ratios of any major property category.

- Sponsorship: Lenders prefer borrowers with pre-existing lender relationships and proven track records, seeking lower LTV ratios. Additional favourable criteria include a borrower's proven commitment to the lodging industry and long-term exit strategy. Additional guarantees or credit enhancements from the hotel operator are also favourable.

\section{Financing vehicles and terms}

Along with the careful evaluation of hotel projects based on the above criteria, private sector debt and equity requirements have become increasingly conservative in recent years, as seen in the descriptions below.

- Permanent loans: Based on research and discussions with lenders, fixed-rate loans for hotels are generally up to ten years at an interest rate of 550 to 650 basis points above LIBOR.

Underwriting criteria include LTV ratios of 55-65 per cent and DSC ratios of 1.4 to 1.5. Adjustable rate loans are generally up to five years.

- Mezzanine financing: With equity becoming more conservative, hotel mezzanine loans have gained in popularity as vehicles to make projects pencil out. Although mezzanine money is typically best suited for potential turnaround situations with strong upside potential - ie an underperforming asset that can be repositioned to market level within a short period of time - mezzanine financing is also often used in development projects. ${ }^{4}$ As mezzanine lenders are frequently active operators attempting to secure the management contract for a development/renovation project, the lender in these cases is well positioned to take over the property if the borrower defaults. Mezzanine loans for hotels - with interest rates generally ranging from 800 to 1,000 basis points above LIBOR - are optimally rolled into more traditional senior loans in 12 to 24 months.

- Equity: Traditionally, private equity has sought leveraged returns in the mid to high 20 per cent range. Based on research and discussions with lenders, private equity is currently priced at returns ranging from 20 to 25 per cent. 


\section{Economic impact}

\section{Development incentives}

\section{The increasingly relevant public sector}

With increasingly high development costs and conservative lending conditions for hotel development projects in the USA, the public sector can play a significant role in assisting private developers take market-viable projects to fruition. Tax and other incentives, as well as low-cost bond financing, are often used by municipalities to push returns above private equity's hurdle rate, while at the same time serving the community by supporting projects that drive economic impact. The following sections discuss public sector motivation and methods for participating in public-private hotel development projects.

\section{Motivation}

The public sector is motivated, in short, by an average of $\$ 1,200$ per visit, according to the 1998 Convention Income Survey Report published by the International Association of Convention and Visitors Bureau Foundation. ${ }^{5}$ This is the average expenditure per delegate for an international, national and regional trade show lasting approximately 3.6 days. Economic impact - including visitor spending on lodging, meals, retail stores, local transportation and other services, tax revenues such as sales and hotel occupancy taxes, employment and indirect impacts due to the 'ripple' effect of large developments on surrounding communities - is the primary motivation for public sector investment in hotel development projects.

Local governments are acutely aware of the economic benefits of overnight visitation to their cities, generated primarily by tourism, commerce and conventions. In order to enhance a convention centre's competitiveness and marketability to associations and meeting planners, and improve overall economic conditions, the public sector has participated with the private sector in a variety of ways to invest in the development of full-service convention centre hotels.

\section{Methods of public sector participation}

In general, the public sector is loath to take on ownership of a hotel, as a municipality generally will not have the requisite experience, or appetite, to be a hotel owner. Instead, the public sector typically utilises a variety of development incentives to encourage private sector investment in hotel projects, the most common of which are discussed below. ${ }^{6}$

- Tax increment financing: The Tax Increment Financing (TIF) Act allows taxing bodies to provide financial support for projects that will generate new employment opportunities, prevent, arrest and alleviate conditions of blight, increase the tax base and improve the general economy. TIF applies a portion of the tax increment from development and redevelopment projects to the repayment of project costs. The tax increment is the difference 


\section{Debt financing} to private developers to make a hotel project come to fruition. In general, three types of financing mechanisms are utilised to fund public-private hotel projects in the USA, described as follows. ${ }^{7}$

- General obligation bonds: General obligation bonds are secured by the full faith and credit of the borrowing government agency. These bonds are guaranteed by a municipality's general fund, which covers all debt not covered by facility revenues. General obligation bonds are considered the most secure form of municipal debt.

- Bonds secured by dedicated taxes/revenue streams: These bonds are secured by specific taxes on revenue streams. It is common for the revenue streams to be attached to commercial activities that will be driven partially by the hotel (eg hotel occupancy). Generally, supporting taxes and revenues may include airport departure, alcohol and tobacco, car rental, admissions, food, beverage and general sales, hotel/motel room, tourist development, utility, construction industry/building trades surcharges, lottery and gaming, parking, taxi and ticket surcharges.

- Lease/revenue-backed bonds: These types of bonds are secured by a pledge by a municipality to cover debt service and are not assigned a dedicated tax or revenue stream, although typically part of the hotel revenue will be used to pay the debt service. This financing approach gives municipalities flexibility to meet 


\section{Financing structure of recent projects}

debt service commitments from any available revenues, but is considered risky as it is generally tied directly to facility performance. Occasionally, bonds issued under this approach are referred to as 'certificates of participation'.

\section{THE DATA - PUBLIC-PRIVATE HOTEL DEVELOPMENT}

This section provides an overview of national trends in publicprivate financing structures for hotels throughout the country. These trends generally support the concept that large, first-class hotels in urban locations require some form of public participation to attract the necessary private financing and equity investment.

The following general trends were identified based on an analysis of 36 public-private hotel projects across the USA. The projects were scheduled or completed over the past decade (1992 through 2002).

- For all 36 projects, private funding totalled 57 per cent of project costs, with the remaining 43 per cent of project costs funded by public sector monies ( 2 per cent in the form of grants, 21 per cent debt financing, 5 per cent occupancy tax rebates or tax abatements, 4 per cent TIF, 2 per cent infrastructure improvements and 9 per cent miscellaneous subsidies such as PILOTS based on favourable ground lease terms). On a per-key basis, private financing totalled approximately $\$ 94,000$, while public financing totalled $\$ 72,000$.

- Projects in the eastern USA were the most expensive, and required the highest percentage of private sector funding. For the 20 projects located in this region, private funding totalled 65 per cent of project costs, while the remaining 35 per cent of project costs was funded by public sector monies. On a per-key basis, private financing totalled approximately $\$ 116,000$, while public financing totalled $\$ 63,000$.

- For the 13 properties in the central portion of the country, the private/public ratio of funding was 50:50, while the three hotel projects in the western USA reported private/public funding ratios of 25:75. On a per-key basis, in central USA, private financing totalled approximately $\$ 71,000$, while public financing totalled $\$ 71,000$; for the western properties, the private and public amounts per key were $\$ 42,000$ and $\$ 125,000$, respectively.

- Regarding the five projects that took place from 1992 through 1997, the public sector contribution was approximately 28 per cent, while those that were scheduled from 1998 through 2003 required a public contribution of 46 per cent. Low-interest debt financing remained the primary vehicle for public sector participation from 1992 through 2003, increasing from 7 to 24 per cent of project costs from the earlier to the latter part of the period.

- For the 18 projects with more than 500 rooms, private funding totalled 54 per cent of project costs, with the remaining 46 per 
cent of project costs funded by public sector monies. On a perkey basis, private financing totalled approximately $\$ 90,000$, while public financing totalled $\$ 78,000$.

- For the 18 projects with 500 rooms or less, private funding totalled 66 per cent of project costs, with the remaining 34 per cent of project costs funded by public sector monies. On a perkey basis, private financing totalled approximately $\$ 105,000$, while public financing totalled $\$ 54,000$.

Table 1 presents a detailed comparison of each of the above categories of public-private hotel project. Table 2 summarises the public and private components for each category of hotel project discussed above.

Of the 36 public-private hotel projects, 16 provided details regarding the specific components of private sector funding (ie equity and debt); approximately 21 per cent of total project costs consisted of private sector equity funding, 48 per cent was comprised of private sector debt financing, and the remaining 31 per cent consisted of public sector monies, as presented in Table 3 .

To summarise, the following trends regarding public-private hotel partnerships are reflected by the above data.

- On a percentage and per room basis, the public sector has participated less in projects in the eastern USA than in the western and central states. While the public sector has invested an average of $\$ 63,000$ per room in projects in the eastern states, comprising approximately 35 per cent of total project costs, it has contributed an average of $\$ 71,000$ and $\$ 125,000$ per room in the central and western regions, comprising 50 and 75 per cent of total project costs, respectively.

- As the decade progressed, the public sector became increasingly involved in hotel projects, with municipal participation increasing from 28 per cent (1992-1997) to 46 per cent (1998-2003). This can be attributed, in large part, to increasing development costs over this period, which averaged approximately $\$ 165,000$ per room in the first half of the decade, and increased by 18 per cent to $\$ 194,000$ per room in the second half.

Table I: Proportions of public and private finance

\begin{tabular}{lcc}
\hline Project category & Estimated private financing & Estimated public financing \\
\hline All projects & 57 & 43 \\
Eastern US projects & 65 & 35 \\
Central US projects & 50 & 50 \\
Western US projects & 25 & 75 \\
Projects scheduled from 1992 through 1997 & 72 & 28 \\
Projects scheduled from 1998 through 2003 & 54 & 46 \\
Hotels with less than or equal to 500 rooms & 66 & 34 \\
Hotels with over 500 rooms & 54 & 46 \\
Range & $25-72$ & $28-75$ \\
\hline
\end{tabular}


Table 2: Public and private components for hotel projects

\begin{tabular}{|c|c|c|c|c|c|c|c|c|c|c|c|c|c|c|c|c|}
\hline & \multicolumn{2}{|c|}{ All projects } & \multicolumn{2}{|c|}{ Eastern USA } & \multicolumn{2}{|c|}{ Central USA } & \multicolumn{2}{|c|}{ Western USA } & \multicolumn{2}{|c|}{$1992-1997$} & \multicolumn{2}{|c|}{ 1998-2003 } & \multicolumn{2}{|c|}{$<500$ rooms } & \multirow{2}{*}{\multicolumn{2}{|c|}{$\begin{array}{l}>500 \text { room } \\
\text { Total }\end{array}$}} \\
\hline & Total & $\%$ & Total & $\%$ & Total & $\%$ & Total & $\%$ & Total & $\%$ & Total & $\%$ & Total & $\%$ & & \\
\hline Number of projects & 36 & & 20 & & 13 & & 3 & & 5 & & 31 & & 18 & & 18 & \\
\hline $\begin{array}{l}\text { Average number } \\
\text { of rooms }\end{array}$ & 620 & & 603 & & 665 & & 533 & & 644 & & 616 & & 321 & & 908 & \\
\hline Number of rooms & 22,303 & & 12,058 & & 8,645 & & 1,600 & & 3,220 & & 19,083 & & 5,959 & & 16,344 & \\
\hline $\begin{array}{l}\text { Estimated cost per } \\
\text { room }(000 \mathrm{~s})\end{array}$ & $\$ 166$ & & $\$ 179$ & & $\$ 142$ & & $\$ 166$ & & $\$ 165$ & & $\$ 194$ & & $\$ 159$ & & $\$ 168$ & \\
\hline $\begin{array}{l}\text { Estimated private } \\
\text { cost per room } \\
(000 \text { s) }\end{array}$ & $\$ 94$ & & $\$ 116$ & & $\$ 71$ & & $\$ 42$ & & $\$ 118$ & & $\$ 105$ & & $\$ 105$ & & $\$ 90$ & \\
\hline $\begin{array}{l}\text { Estimated public } \\
\text { cost per room } \\
(000 \text { s) }\end{array}$ & $\$ 72$ & & $\$ 63$ & & $\$ 71$ & & $\$ 125$ & & $\$ 46$ & & $\$ 89$ & & $\$ 54$ & & $\$ 78$ & \\
\hline \multicolumn{17}{|c|}{ Private (in millions) } \\
\hline Subtotal & $\$ 2,158.4$ & $57 \%$ & $\$ 1,398.6$ & $65 \%$ & $\$ 693.2$ & $50 \%$ & $\$ 66.6$ & $25 \%$ & $\$ 381.0$ & $72 \%$ & $\$ 1,777.4$ & $54 \%$ & $\$ 626.8$ & $66 \%$ & $\$ 1,531.6$ & \\
\hline$\%$ private & $57 \%$ & & $65 \%$ & & $50 \%$ & & $25 \%$ & & $72 \%$ & & $54 \%$ & & $66 \%$ & & $54 \%$ & \\
\hline \multicolumn{17}{|l|}{ Public (in millions) } \\
\hline Grant & $\$ 73.6$ & $2 \%$ & $\$ 39.2$ & $2 \%$ & $\$ 11.0$ & $1 \%$ & $\$ 23.4$ & $9 \%$ & $\$ 11.0$ & $2 \%$ & $\$ 62.6$ & $2 \%$ & $\$ 30.6$ & $3 \%$ & $\$ 43.0$ & \\
\hline Debt financing & $\$ 812.8$ & $21 \%$ & $\$ 273.3$ & $13 \%$ & $\$ 456.5$ & $33 \%$ & $\$ 83.0$ & $31 \%$ & $\$ 35.2$ & $7 \%$ & $\$ 777.6$ & $24 \%$ & $\$ 57.1$ & $6 \%$ & $\$ 755.7$ & 2 \\
\hline $\begin{array}{l}\text { Occupancy tax } \\
\text { rebate/tax } \\
\text { abatement }\end{array}$ & $\$ 200.8$ & $5 \%$ & $\$ 113.8$ & $5 \%$ & $\$ 87.0$ & $6 \%$ & $\$-$ & $0 \%$ & $\$-$ & $0 \%$ & $\$ 200.8$ & $6 \%$ & $\$ 14.3$ & $2 \%$ & $\$ 186.5$ & \\
\hline \multicolumn{17}{|l|}{ Tax increment } \\
\hline financing & $\$ 139.2$ & $4 \%$ & $\$ 103.8$ & $5 \%$ & $\$ 35.4$ & $3 \%$ & $\$-$ & $0 \%$ & $\$-$ & $0 \%$ & $\$ 139.2$ & $4 \%$ & $\$ 33.7$ & $4 \%$ & $\$ 105.5$ & \\
\hline $\begin{array}{l}\text { Infrastructure } \\
\text { Other }\end{array}$ & $\$ 71.6$ & $2 \%$ & $\$ 54.0$ & $3 \%$ & $\$ 17.6$ & $1 \%$ & $\$-$ & $0 \%$ & $\$ 36.8$ & $7 \%$ & $\$ 34.8$ & $1 \%$ & $\$ 50.6$ & $5 \%$ & $\$ 21.0$ & \\
\hline $\begin{array}{l}\text { Other } \\
\text { Subtotal }\end{array}$ & $\$ 349.0$ & $9 \%$ & $\$ 176.0$ & $\begin{array}{r}8 \% \\
35 \%\end{array}$ & $\begin{array}{r}\$ 80.0 \\
\$ 6875\end{array}$ & $\begin{array}{r}6 \% \\
50 \%\end{array}$ & $\begin{array}{r}\$ 93.0 \\
\$ 199.4\end{array}$ & $\begin{array}{l}35 \% \\
75 \%\end{array}$ & $\$ 66.5$ & $\begin{array}{l}13 \% \\
28 \%\end{array}$ & $\$ 282.5$ & $\begin{array}{r}9 \% \\
46 \%\end{array}$ & $\$ 135.5$ & $\begin{array}{l}14 \% \\
34 \%\end{array}$ & $\begin{array}{r}\$ 213.5 \\
\$ 13252\end{array}$ & \\
\hline $\begin{array}{l}\text { Subtotal } \\
\% \text { public }\end{array}$ & $\begin{array}{c}\$ 1,647.0 \\
43 \%\end{array}$ & $43 \%$ & $\begin{array}{l}\$ 160.1 \\
35 \%\end{array}$ & $35 \%$ & $\begin{array}{l}\$ 68 / .5 \\
\mathbf{5 0 \%}\end{array}$ & $30 \%$ & $\begin{array}{l}\$ 199.4 \\
\mathbf{7 5 \%}\end{array}$ & $15 \%$ & $\begin{array}{l}\$ 149.5 \\
\mathbf{2 8} \%\end{array}$ & $28 \%$ & $\begin{array}{c}\$ 1,49 / .5 \\
46 \%\end{array}$ & $46 \%$ & $\begin{array}{l}\$ 321.8 \\
34 \%\end{array}$ & $34 \%$ & $\begin{array}{c}\$ 1,325 \% 2 \\
46 \%\end{array}$ & \\
\hline Total & $\$ 3,805.4$ & $100 \%$ & $\$ 2,158.7$ & $100 \%$ & $\$ 1,380.7$ & $100 \%$ & $\$ 266.0$ & $100 \%$ & $\$ 530.5$ & $100 \%$ & $\$ 3,274.9$ & $100 \%$ & $\$ 948.6$ & $100 \%$ & $\$ 2,856.8$ & 100 \\
\hline
\end{tabular}

Table 3: Projects with private financing details

\begin{tabular}{lcc}
\hline & Total & $\%$ \\
\hline Number of projects & 16 & \\
Average number of rooms & 431.9375 & \\
Number of rooms & 6,911 & \\
Estimated cost per room (000s) & $\$ 163$ & \\
Estimated private cost per room (000s) & $\$ 112$ & \\
Estimated public cost per room (000s) & $\$ 51$ & $21 \%$ \\
& & $48 \%$ \\
Private (in millions) & $\$ 230.0$ & \\
Equity & $\$ 544.8$ & \\
Debt & $\$ 774.8$ & $3 \%$ \\
Subtotal & $\mathbf{6 9 \%}$ & $11 \%$ \\
\% private & & $2 \%$ \\
Public (in millions) & $\$ 32.6$ & $5 \%$ \\
$\quad$ Grant & $\$ 121.3$ & $0 \%$ \\
Debt financing & $\$ 21.8$ & $31 \%$ \\
Occupancy tax rebate/tax abatement & $\$ 120.7$ & \\
Tax increment financing & $\$ 53.6$ & $100 \%$ \\
Infrastructure & $\$ 0.0$ & \\
Other & $\$ 350.0$ & \\
Subtotal & $31 \%$ & \\
\% public & & \\
Total & $\$ 1,124.8$ &
\end{tabular}


Variables

\section{Time commitment}

\section{Benefits}

- A similar relationship can be observed with respect to the ratio of public sector participation in large versus small hotel projects. As the size of the project increases, the percentage of public sector investment increases, reflecting the higher costs (on a total and per room basis) of the larger projects. Hotels with more than 500 rooms required public sector investment of 46 per cent of total project costs, while hotels with 500 rooms or less required only 34 per cent of costs from the public sector.

\section{CONCLUSION - A CHALLENGE BUT WORTH IT}

Public-private hotel partnership structures are often complex and require a high degree of creativity; they can involve several variables including financing techniques and structure; design, construction and operational responsibilities and risk; ownership position and risk; distribution of non-tax income and tax revenue; quality control; and predevelopment and development scheduling. Variables such as political interests, political instability and/or the ending of a key political leader's term in office can also affect a public-private partnership.

Additionally, taxpayers and voters expect government officials to realise significant value from tax dollars while avoiding tax increases; therefore, expensive, high-profile hotel projects are often scrutinised by local residents. Due to this high level of scrutiny, as well as the typical complexity of the project, public-private development partnerships can take a long time to structure and approve. Frequently, community opposition comes from business or special-interest groups which have only a limited or no vested interest in the project; this is exacerbated in cases where the public agency sponsoring the project may not have the authority to provide the assistance required to structure a partnership that is subject to perceived risk. ${ }^{8}$

Ultimately, for projects that are market viable, these partnerships are mutually beneficial to each participant. While public entities can provide incentives, private developers can contribute invaluable knowledge and insight on national and local markets, entrepreneurial orientation, vision and creativity, development and management skills, advice regarding a prospective hotel operator and risk capital. While the public sector realises its goals with respect to economic impact and community revitalisation, the private sector achieves its desired return on investment. It stands to reason, then, that as the costs involved with developing large, firstclass hotels continue to increase, the proportion of public sector participation will also continue to rise.

\section{References}

1. Wood, M. (2001) 'Debt slows to a trickle', Real Estate Forum - Hotel Finance Review, October.

2. Jones Lang LaSalle Hotel (2001) 'Focus On: The Impact of the September 11, 2001 Terrorist Attacks on the US Hotel Real Estate Market'.

3. Moody's Investor Service (2001) Special Report - CMBS, August. 
4. Wood, ref. 1 above.

5. International Association of Convention and Visitors Bureau Foundation (1998) Convention Income Survey Report.

6. Empire State Development Corp. Incentives Platform (2000).

7. Tradeshow Week magazine commissioned research (2001).

8. Representatives of public-private hotel partnerships, Urban Land Institute and Strategic Advisory Group. 